\title{
Empirical Testing of Real Options in the Hong Kong Residential Real Estate Market
}

\author{
Huimin YAO \\ Email: yaohmin@hkusua.hku.hk \\ Frederik Pretorius \\ Email: fredpre@khucc.hku.hk \\ Department of Real Estate and Construction \\ The University of Hong Kong
}

\begin{abstract}
Hong Kong has been using the leasehold system of land management rather than freehold since its colonial era. This system controlled and presently still controls uses of leased land through leasehold conditions. Many leases granted decades ago thus require formal modifications to lease conditions to formalize proposed changes in land use, or to realize the actual present economic value of the land, or to reflect the current market demands. From a real options analysis perspective, these land use conversions and analysis of real options associated therewith are significantly more complex than typical stylized land development real options encountered in academic literature and research. There is thus considerable interest in obtaining empirical evidence of the performance of real options valuation in land development applications, where options associated with land development rights are substantially constrained due to regulatory influences. The aim of this research is to outline major factors in operationalizing academic real options research for practical application in a particular land market with significant regulatory constraints, and then test two propositions derived from academic real options literature using actual residential real estate development projects in Hong Kong which require leasehold land conversion under statutory planning and zoning regulations as source of data. Typically past land use conversions in Hong Kong required developers to acquire raw or other redevelopable land through private negotiations with initial land lease owners and to wait for public provision of infrastructure and services, before applying for formal and legal conversion from a lower to higher land use. Our study concentrates on the period between when land is acquired and when actual construction of the development starts, and as becomes clear, the regulatory framework that governs land development significantly narrows typical real options as perceived in academic land development literature.
\end{abstract}

Keyword: Lease modification; real option; empirical testing 


\section{Introduction and Objectives}

Hong Kong has used the leasehold system of land management rather than freehold since its colonial era. This system controlled and presently still controls uses of leased land through leasehold conditions, while new or renewed leases regulate land uses by zoning regulations functioning through statutory town planning, and with appropriate conditions incorporated in new leases. Since many leases were granted decades ago, these old land leases thus require lease modifications to formalize proposed changes in land use to realize the actual present economic value of the land, or to reflect current market land use demands. From a real options analysis perspective, these land use conversions and analysis of real options associated therewith are significantly more complex than typical stylized land development real options encountered in academic literature and research. There is thus considerable interest in obtaining empirical evidence of the performance of real options valuation in land development applications, where options associated with land development rights are substantially constrained due to regulatory influences.

Typically lease modifications are allowed following entrepreneurial land purchase by developers and then negotiation between the government and the developer to change land use, subject to land use planning and other regulatory constraints; and in exchange for a fee known as a "land premium" (comparable to a betterment tax in many jurisdictions). This process is commercially extremely risky and resembles a series of real options, for example, which allow strategic actions at various stages. From land use conversion until eventual land development, the main concerns of the developer remain to minimize the amount of land conversion fee if he chooses to convert the land to a higher use, and optimally time the development of the land to capitalize on rising market trends for realizing maximum profit. Our study concentrates on the period between when raw land is acquired and when actual construction of the development starts, and as becomes clear, the regulatory framework that governs land development significantly narrows typical real options as perceived in academic land development literature.

\section{Institutional Environment Surrounding Lease Modification}

Before proceeding further, a brief introduction of the institutional environment surrounding lease modification is necessary. In Hong Kong, land conversion procedures requiring lease modification are more complex than they appear in the real options literature. At the land conversion stage, the developer has acquired the raw land through private negotiation with initial land lease owners, held the piece of land, waiting for infrastructure brought into this area, and thus formal and legal conversion from a lower use to a higher use. Our concern is to concentrate on the period between when raw land is bought and when actual construction of 
the development starts. Once a real estate development company bought this lease over raw land, it is in a position to start investing further in its proposed development of the land. So it is like an $\mathrm{R} \& \mathrm{D}$ project- it has to invest more in its idea to develop the land. When it has completed its investigation, it presents its proposals to the government for consideration, whereafter there is negotiation between real estate firms and the government.

During the negotiation process between the lessee and the government, the government may impose conditions they think fit, or conditions advised by other department, such as Planning Department. As a result, current planning conditions can be applied through the lease modification process. In Hong Kong, in most cases before the lessee applies for lease modifications, approval from the Town Planning Board for the change of use of the subject site is required. This is usually achieved through the planning application under the Town Planning Ordinance for areas covered by the statutory plans, i.e. Outline Zoning Plans (OZP) or Development Permission Plans (DPA). Upon receipt of the planning statement from the applicant, the reports will be circulated among different departments for comments. In many cases, conditions are attached to approved decisions if the application is not being rejected. Development densities, restrictions such as usage, site coverage, gross floor area and other regulatory constraints that would govern the development on the land are effectively decided by the government. So, the initial permission is actually a conditional permission. It often happens that the problem with decisions relating to land use is not over the question of whether the development should be permitted at all, but on what terms it should be permitted. Conditions may be imposed, therefore, not only to enhance the quality of the development but to ameliorate any adverse effects that might otherwise flow from the development. This can be a very useful way of permitting development which would otherwise be undesirable in areas where there is no or inadequate statutory planning control, for instance, in areas not covered by existing statutory plans(Ying, 1993). So, the regulatory framework that governs land development significantly narrows typical real options as perceived in academic land development literature.

\section{Identifying Real Options in the process of lease modification}

From the above introduction, we can see that the investment made in the "research and development" phase by real estate development firms remains risky because of the often uncertain imposed regulatory conditions by the government. However, there is one very important strategic variable that the real estate development firm can influence here- the timing of formal and legal conversion of land uses, i.e., the timing of paying the land conversion premium to the government. Once there is agreement by the government on all the constraints that will govern the development, the government and the real estate development firm will sign a formal agreement: the government agrees to enter into a new lease with the 
real estate firm under the new agreed land use agreements, at a fee—land premium—payable to the government because the new land use is higher than the previous land use. When the market is high, the fee will be high, and vise versa. But the real estate firm does not have to pay this land conversion fee immediately when agreement has been reached with the government - in fact, this fee is payable only when the real estate firm formally enters into the new lease. It will only enter into the new lease and formally pay the fee when it chooses to do so. So when to pay this land conversion fee and thus formal conversion of land uses is an important timing decision. There is an advantage to defer the payment of the land conversion fee until it is expected to be most favorable for the real estate firms. In fact, after purchasing land from others, some owners have waited as long as 60 years before applying for lease modification. After paying of the land conversion premium, the developer still holds another important option - the timing of the start of the construction. Although there are stringent time restrictions in the building covenant (BC) attached to the land use conversion contract, there still remains some time flexibility for the developer to delay the construction after paying the "penalty fee” to the government and being approved of an extension of the BC period. Also, there are other procedural and administrative measures that the developer can use to delay the actual construction if there is much uncertainty about the future market trend, for example, the developer can delay the engineering process of the foundation works. So from the whole process from formal land use conversion to eventual land development, the land development option associated therewith can be roughly modeled as a perpetual American call option.

\section{Research Objectives}

Most big developers in Hong Kong own significant land banks. When market prices are low, they attempt to absorb land for low land prices (e.g., often agricultural land from farmers). When market prices are high, they attempt to capture favorable market conditions and get properties onto the market in time to benefit from high prices. However, the previous lower land use has to be converted to a higher land use before construction (e.g., agricultural use convert to residential use or industrial use convert to commercial use). So before commencement of construction, developers have to apply for planning modification to the government. At times when Hong Kong government temporarily terminates land auctions in the open market, applying for lease modification for land in one's land bank is a major means of obtaining developable land for most big developers in Hong Kong. The aim of this research is to outline major factors in operationalizing academic real options research for practical application in a particular land market with significant regulatory constraints, and then test two propositions derived from academic real options literature using actual residential real estate development projects in Hong Kong which require leasehold land conversion under statutory planning and zoning regulations as source of data. 


\section{Literature Review and Statement of Propositions / Hypotheses}

This section reports literature review on empirical testing of land option pricing model. Following literature review, we will explicitly state research propositions/hypotheses.

\section{Literature Review on Empirical Testing of Land Option Pricing Model}

Empirical testing of real option pricing is a relatively new field. Using market data from two different newly constructed residential condominium developments in Louisiana, U.S., Shilling, Benjamin and Sirmans (1985) show that by signing a normal purchase contract, a condominium buyer can be viewed as having purchased a European call option. Their simulation results suggest that standard industry practices of charging a fixed amount for the option to purchase roughly conform to the pricing behavior dictated by option pricing behavior. The lack of transaction data has been identified as one of the major obstacles for the empirical evaluation of real options. Quigg(1993)'s paper is the first effort that examines the empirical predictions of a real option-pricing model using a large sample of land market transaction prices. Using data on 2700 land transactions in Seattle, the author finds a mean option (time) premium of $6 \%$ of the theoretical land value. The author finds that the option valuation model has explanatory power over and above the intrinsic value model (which does not value the option to wait), for predicting land market transaction prices and proposes that land prices valuation models should account for the option to wait. One of the shortcomings in her research is that the price of the building is not observable and thus must be estimated by hedonic estimation. In our research, we try to overcome this problem and select such data that the building (the underlying asset) has been completed and sold and of course the pricing of the building (or unit price) can be estimated in a narrow range following planning regulations. Quigg(1993), in her discussions about avenues for future research, suggests that "an alternative test might also examine the exercise policy of the developer to gauge whether development did actually occur at the optimal point predicted by the option-based model”(1993: 639). Our research, following the spirit of Quigg(1993)'s empirical work, try to fill this gap and examine the exercise policy of the developer and empirically test whether land development did actually occur at the optimal point predicted by the option-based model using Hong Kong’s market data.

Sing and Patel (2001a) use a sample of data from 2286 property transactions in the UK collected over a 14-year sample period from 1984-1997 to estimate the premium for the option of waiting to develop. Based on a one-factor contingent claim valuation model, they found that the average premiums for the timing options were 28.78 percent for office sector, 25.75 percent for industrial sector and 16.06 percent for retail sector. Using 4368 land price data from 1985 through 2000 in Tokyo, Yamazaki (2001) empirically tests real option pricing models utilizing both time-series economic data and cross-sectional lot-specific data. The 
results from the option-based models favor the application of the real option theory in land prices. The total uncertainty with respect to built asset return has a substantial effect on increasing land prices, which implies that an increase in uncertainty leads to an increase in land prices. Capozza and Schwann(1990) tested the urban asset pricing model and focused on the empirical dimensions of the effects of risk on urban land prices. The effects of systematic and unsystematic risk are distinguished in the model, which incorporates the value of the option to convert land to urban uses into the pricing of urban real estate. In their sample, unsystematic risk is a larger proportion of total risk than systematic risk. The effect of total risk on land prices is illustrated through the irreversibility premia estimates. In the two regions where the irreversibility premia are statistically significant, it accounts for $22 \%$ and $53 \%$ of the average housing prices. Capozza and Schwann(1990)'s results highlight the importance of risk in determining urban land prices, which corresponds closely to the results of Yamazaki(2001).

To examine the role of uncertainty in investment, Holland, Ott and Riddiough(2000) empirically test the uncertainty-investment relationship using aggregate data(quarterly time-series data from 1972 through 1992) on various categories of commercial real estate, including apartments, office, retail and industrial properties. They find a statistically and economically significant short-term negative relationship between total uncertainty and the rate of investment for most types of commercial real estate included in this study and the evidence favors the option-based model over the neoclassical model. To explore the empirical relevance of the theory of irreversible investments in explaining movements in office-commercial completions, Sivitanidou and Sivitanides(2000) extend the traditional empirical model of new construction to account for the volatility of underlying demand movements using updated time-series of office-commercial construction across the largest U.S. metropolitan markets during 1982-1998. The empirical results highlight both the relevance and the relative importance of volatility in demand factors in shaping movements in office-commercial construction, while pointing altogether to more cautionary investment behavior during the more uncertain post-recession period. Sing and Patel (2001b) have also provided evidence of irreversibility in the UK property market. Their study has examined how investment decisions at three main stages of the property development/investment processes respond to different sources of uncertainty. Their empirical findings are generally consistent with the prediction of the real option theory that uncertainty increases the option value to wait for the arrival of new information thus decreasing the current investment activities. In periods of high volatility, the authors would expect investors in the property market to be more prudent and scale down their investment exposure to market volatility compared with periods of a relatively stable market environment. 
Bulan, Mayer and Somerville (2002) examine 1214 condominium developments in Vancouver, Canada between 1979-1998 to identify the extent to which uncertainty delays investment. They find that increases in both idiosyncratic and systematic risk lead developers to delay new real estate investments. In particular, they show that investment activity falls with increases in uncertainty. The probability of development occurring at a given site is negatively related to the volatility of returns. Increases in the number of potential competitors located near a project negated the negative relationship between idiosyncratic risk and development. These findings provide unambiguous support for the existence of a call option in the ability to delay irreversible investment.

\section{Propositions}

From the review of literature, we can see that developable land may be viewed as a perpetual “American” call option on underlying asset that pays “dividends”. Real estate development is like corporate capital budgeting in that the underlying asset is real physical capital (the building to be built); hence we are dealing with "real options". However, there is an important difference between the real estate development case and the corporate capital budgeting case. Unlike the corporate capital budgeting case (but more like the case of traded financial options), in real estate development there is a functioning market for the real option, namely, the land market. If the land market is functioning well, the market value of land should reflect the option value inherent in the land ownership, including the value of any "option premium" (the component above the current exercise value of the option). So land is an option and land value is actually "option value". There are some distinguishing characteristics of the land development option: (1) it is perpetual (no expiration), which allows more flexibility (greater value) and the only reason to exercise is to obtain operating cash flows; In Hong Kong, land development option associated with lease modification can be roughly regarded as "perpetual" because the developer can freely choose the time when land conversion is done and some even wait for decades of years before conversion. (2) there is also a "time to build" effect (exercise is not immediate), and developers cannot observe exact at-completion market value of underlying asset at the time the exercise decision is made (which means added risk in exercise decision). Much uncertainty can exist between the decision to develop and completion of that development; (3) "noisy" value observation of (even current) market value of underlying asset (the to-be-built property): some developers may be more knowledgeable than others (wait longer until exercise); (4) exercise creates new real assets that add to the supply side of the space market (affecting market value of all competing properties), which can increase risk of not exercising (option may effectively "expire” if demand is absorbed by competing development projects). These characteristics all apply in Hong Kong.

While recent mostly empirical work concentrates on testing of evidence of irreversibility in 
real estate, i.e., testing of the negative relationship between real estate investment activity and volatility in real estate returns, just a few empirical research papers concentrates on empirical testing of option premium in real estate, e.g., Quigg(1993) and Sing and Patel(2001a). Unlike the work done by Quigg(1993) and Sing and Patel(2001a), our research would examine the option premium in real estate using a case study approach rather than statistical testing and using the data from real and completed development projects in Hong Kong.

From review of standard approach for assessing land use conversion premium in Hong Kong by government, we can see that by paying the land conversion premium, the developer actually obtains the option to develop the converted land at an optimal time. So the land conversion premium can thus be regarded as the "option price" paid to the government for the option to develop the land at an optimal time held by the developer. The government sells the option to the developer. The approach adopted by government is the traditional residual value method based on net present value of immediate development of land at the current time and does not account for the value of options held by the developer to wait for conversion and construction in the future. So we can hypothesize that the land premium obtained by the Hong Kong government is actually the intrinsic value of an option, not taking account of time (option) premium. This research outlines major factors in operationalizing academic real options research for practical application in a particular land market with significant regulatory constraints, and tests two propositions: (1) there is a significant and positive difference between the land conversion premium calculated by option pricing theory and the land conversion premium calculated by the authorities (based on DCF principles); and (2) developers are expected to delay the development of land to the point predicted by the real options model even when regulatory constraints are incorporated into the analyses.

\section{Methodology and Data}

The method to test proposition 1 follows in principal the methodology by Quigg(1993). In Quigg(1993)'s empirical testing of option premium, the option value of vacant land is known. It is assumed to be the transaction price of land in the land market in Seattle. The intrinsic value of land (option) is unknown and needs to be estimated assuming immediate development of land using hedonic pricing methodology. In our research, we know the intrinsic value of land. It is the land conversion premium calculated by the residual method assuming immediate development. The option value of land is unknown. We have to first estimate the option value of land by option pricing methodology. The difference between the land conversion premium calculated by the option pricing method and the land conversion premium calculated by the residual value method assuming immediate development divided by the land conversion premium using the option pricing method is the option(time) premium in our research. The method for testing proposition 2 follows in principle the methodology by 
Samuelsom and Mckean(1965). We calculate the theoretical critical value of underlying asset at which it is optimal to build and compare it to the actual value of underlying asset when the developer starts to build and compare them.

\section{Option Pricing Model}

The model that we choose for calculating the perpetual call option value is as follows:

Consider the state variable-the value of the building $(V)$ follows the following geometric Brownian motion:

$$
d V=\alpha V d t+\sigma V d z
$$

Where $\alpha$ and $\sigma$ are the instantaneous drift (expected capital appreciation rate) and standard deviation of the cash flow stream, $d z$ is an increment of the standard Wiener process with a normal distribution $[N \sim(0,1)]$.

We value the option (land) by contingent claims analysis. Assume changes in $V$ are spanned by existing assets; no taxes or transaction costs; short selling is possible. First construct a riskless portfolio. Portfolio in $t$ is:

$$
V \phi=L(V)-L^{\prime}(V) V .
$$

Where $L(V)$ is the value of the land or the development option and short selling of $L^{\prime}(V)$ units of an asset which are perfectly correlated with $P$.

By Ito's lemma, change of the portfolio value over a short time interval $d t$ is:

$$
\begin{aligned}
& d \phi=d L-L^{\prime}(V) d V-\delta V L^{\prime}(V) d t \\
& =L^{\prime}(V) d V+0.5 L^{\prime \prime}(V)(d V)^{2}-L^{\prime}(V) d V-\delta V L^{\prime}(V) d t \\
& =0.5 L^{\prime \prime}(V)(d V)^{2}-\delta V L^{\prime}(V) d t \\
& =0.5 \sigma^{2} V^{2} L^{\prime \prime}(V) d t-\delta V L^{\prime}(V) d t
\end{aligned}
$$

There is no $d z$ term in the above equation, which means that the portfolio is riskless and its return must be equal to

$$
r \phi d t=r\left(L(V)-L^{\prime}(V) V\right) d t
$$

Setting $d \phi=r \phi d t$ and rearranging gives partial differential equations:

$$
0.5 \sigma^{2} V^{2} L^{\prime \prime}(V)+(r-\delta) V L^{\prime}(V)-r L=0
$$

With boundary conditions:

$$
L(0)=0 ; L\left(V^{*}\right)=V^{*}-K ; L^{\prime}\left(V^{*}\right)=1
$$


The value for call option (land) value is:

$$
L=\left(V^{*}-K\right)\left(\frac{V}{V^{*}}\right)^{\eta}
$$

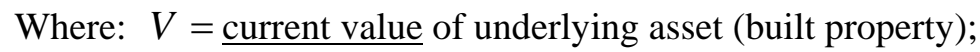

$K=\underline{\text { Strike price }}$ (construction cost excluding land cost);

$V^{*}=$ Critical value (hurdle value) of underlying asset at and above which it is optimal to immediately exercise the option (develop the land);

$\eta=$ Elasticity of option.

The Samuelsom-Mckean formula specifies option elasticity as:

$$
\eta=\left(\delta-r+\sigma^{2} / 2+\left(\left(r-\delta-\sigma^{2} / 2\right)^{2}+2 r \sigma^{2}\right)^{1 / 2}\right) / \sigma^{2}
$$

Where:

$\delta$ is the payout ratio of the built property (current cash yield rate, like capitalization rate only net of capital improvement reserve, typical real estate values range form $4 \%$ to $12 \%$ ); $r$ is the risk-free rate (e.g., short-term T-bill yield, typically 3\% to $6 \%$ ); $\sigma^{2}$ is the volatility of (or standard deviation of return to unlevered) individual built properties, not just systematic or non-diversifiable risk, includes idiosyncratic risk: typical range for real estate is $15 \%$ to $25 \%$ per year. For present purposes, volatility is taken to be constant, an easily modified assumption.

The real options model also defines critical value of underlying asset as:

$$
V^{*}=K \eta /(\eta-1)
$$

$V^{*}$ represents the hurdle value of the building upon which below such a value the land should be left undeveloped.

Form this formula, we can derive the critical benefit-cost ratio at which it is optimal to build as:

$$
\frac{V^{*}}{K}=\frac{\eta}{\eta-1}
$$

The hurdle benefit/cost ratio $\left(V^{*} / K\right)$ represents the ratio of built property value divided by construction cost exclusive of land cost, which triggers immediate optimal development and is a function only of option elasticity. It tells you how much greater the anticipated completed new built property value (including land) must be greater than its construction cost (excluding land), in order for it to be optimal to stop waiting to develop, and immediately begin (instantaneous) construction. The hurdle benefit/cost ratio is increasing with the risk-free rate 
$(r)$ and deceasing with the built property current cash yield ( $\delta$ ) and increasing with the volatility of the built property asset value $(\sigma)$.

We do not use "Black-Scholes", because the "Black-Scholes”formula is either for "European" options (that cannot be exercised prior to maturity), or “American” options on underlying assets that do not pay dividends, and is for options with finite maturity. Instead, we use the "Samuelsom-Mckean formula", first published in 1965 by Paul Samuelson and Henry Mckean and rediscovered in 1980s by McDonald and Siegel in evaluating the value of "waiting to invest". It is similar to models of "optimal development" in a "stochastic city" developed in late 80s/early 90s by Capozza, Helsley and Willams, among others. The Samuelsom-Mckean formula applies to a perpetual American call option on a dividend-paying underlying asset, and so it is perfect for our land application.

We will use the case study approach to test the above two propositions. In lease modification in Hong Kong, we select the data of lower land use converted for residential use in Tuen Mun and Yeun Long Districts in the New Territory of Hong Kong. Selective cases would be analyzed extensively and thoroughly. The data required by proposition 1 and proposition 2 can be the same data. We first identify appropriate projects and then buy land use conversion contracts and other related contracts from Hong Kong government.

\section{Results}

For purposes of this paper, we set about analyzing three cases of land conversions in the Tuen Mun/Yuen Long new towns in Hong Kong. We obtained contractual lease modification documentation for land lease cases from the Land Registry of the Hong Kong Government. From the signed contracts, we obtained the land premium calculated by government and the time when the developer actually paid the land conversion premium to the government. The critical variables that must be estimated for every project are volatility of returns, dividend yield, risk free rate, the current value of the underlying asset and the construction cost (exercise price) when the land premium was paid. From these data, we can estimate the value of the land (option) using the formula in equation (6).

Volatility of returns is estimated from the repeat-sales monthly index for the residential sector (non-age-adjusted) of Hong Kong, a customized index at the University of Hong Kong (Wong, 2003). The dividend yield is estimated from the statistical data for the private domestic-average rentals by class and private domestic--average prices by class in the journal of Hong Kong Property Review. The risk free rate is estimated from one-year US government treasury bills (the cases precede the creation of the Hong Kong Monetary Authority, and the Hong Kong Exchange Fund Bills and Notes program). For the estimation 
of the current value of the underlying asset, transaction prices of comparable residential properties surrounding the subject property at the time the premium was paid have been used. For the estimation of construction cost, the approximate order of construction cost by Levett and Bailey Chartered Quantity Surveyors at the time the premium was paid has been used. To calculate the land value before modification, we use the Historical and Current Land Records drawn from the land registry and compounded the value by Hong Kong InterBank Offered Rate (HIBOR) when there is time lag between the land purchase transaction and land use modification. From these data, we calculate the land premium by option pricing methodology and compare the results with the premium the government calculated. To test whether the developer has optimally exercised the option or not, we calculate the critical value of the underlying asset at the time the premium was paid and compare this value with the current value of underlying asset at the time the premium was paid. Because at the time the premium was paid the construction did not commence, from the comparison of the two values, we can roughly estimate whether the developer has optimally exercised his option or not. The details of the projects are in the appendixes of this paper. The following are the results of the real option analysis.

\subsection{Results of Case 1-- Parkland Villas Block}

\subsubsection{See the following graph for the estimation of variables}

\begin{tabular}{|c|c|}
\hline Variables & Estimation of Variables \\
\hline $\begin{array}{l}\text { Volatility of real estate asset returns } \\
\text { between } 1983 \text { to } 1994(\sigma)\end{array}$ & 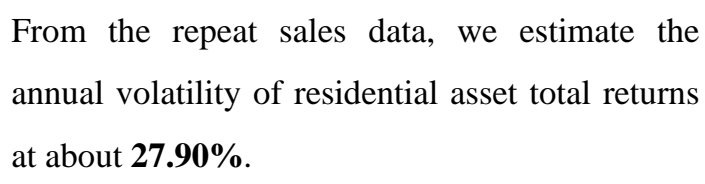 \\
\hline Dividend Yield of Land Option ( $\delta$ ) & $\begin{array}{l}\text { Dividend yield of land option is rental yield of } \\
\text { built property. We estimate the average rental } \\
\text { yield at about } 4.77 \% \text { at the time the premium } \\
\text { was paid. }\end{array}$ \\
\hline Risk-free Rate of Return & $\begin{array}{l}\text { The rate is } \mathbf{5 . 3 8 \%} \text { at the time the premium was } \\
\text { paid. }\end{array}$ \\
\hline $\begin{array}{c}\text { Strike Price (construction cost) of Land } \\
\text { Option }\end{array}$ & $\begin{array}{l}\text { We estimate the strike price of land option at } \\
\text { about } 499,703,969 H K \$ \text { by using the open } \\
\text { market information at the time the premium was } \\
\text { paid. }\end{array}$ \\
\hline $\begin{array}{l}\text { Current Value of Underlying Asset (built } \\
\text { property) at the time land premium was } \\
\text { paid }\end{array}$ & $\begin{array}{l}\text { We estimate the current value of underlying asset } \\
\text { at about } \mathbf{1 , 1 8 1 , 2 1 9 , 7 7 4} \mathbf{H K} \mathbf{\$} \text { by using open } \\
\text { market information at the time the premium was } \\
\text { paid. }\end{array}$ \\
\hline
\end{tabular}




\subsubsection{Option Pricing and Option (time) Premium}

By using option pricing methodology, we estimate the land premium at about HK\$ $391,850,034$. The land premium estimated by the government is HK\$ 356,250,000. The land premium estimated by the option pricing theory is larger than that of the government using residual method, which supports our propositions. The option premium is about $\mathbf{9 . 0 9 \%}$. Also, we estimate the current value of the underlying asset at the time the premium is paid at about HK\$ 1,181,219,714, which is smaller than the critical value of the underlying asset of this land option at the time the premium was paid(HK\$1,245,494,554). This means that this land option is an out-of the-money call option and if this option is exercised immediately, then the developer would suffer a redued profit. The exercise practice of the developer at a later time conforms the predictions of the option theory.

\subsection{Results of Case 2-- Bauhinia Garden}

\subsubsection{See the following graph for the estimation of variables}

\begin{tabular}{|c|c|}
\hline Variables & Estimation of Variables \\
\hline $\begin{array}{l}\text { Volatility of real estate asset returns } \\
\text { between } 1983 \text { to } 1992(\sigma)\end{array}$ & $\begin{array}{l}\text { From the repeat sales data, we estimate the } \\
\text { annual volatility of residential asset total returns } \\
\text { at about } \mathbf{2 9 . 7 4 \% .}\end{array}$ \\
\hline Dividend Yield of Land Option ( $\delta$ ) & $\begin{array}{l}\text { Dividend yield of land option is rental yield of } \\
\text { built property. We estimate the average rental } \\
\text { yield at about } \mathbf{5 . 9 9 \%} \text { at the time the premium } \\
\text { was paid. }\end{array}$ \\
\hline Risk-free Rate of Return & $\begin{array}{l}\text { The rate is } \mathbf{4 . 0 7 \%} \text { at the time the premium was } \\
\text { paid. }\end{array}$ \\
\hline $\begin{array}{c}\text { Strike Price (construction cost) of Land } \\
\text { Option }\end{array}$ & 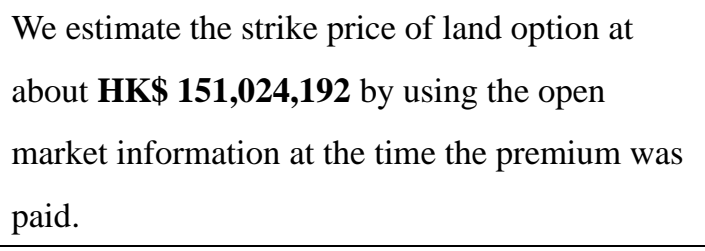 \\
\hline $\begin{array}{c}\text { Current Value of Underlying Asset (built } \\
\text { property) at the time land premium was } \\
\text { paid }\end{array}$ & 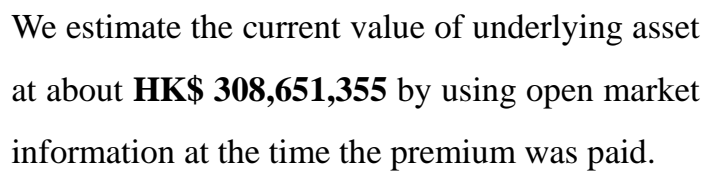 \\
\hline
\end{tabular}

\subsubsection{Option Pricing and Option (time) Premium}

By using option pricing methodology, we estimate the land premium at about HK\$ $122,125,803$. The land premium estimated by the government is HK\$ $107,770,000$. So the land premium estimated by the option pricing theory is larger than that of the government using residual method, which supports our propositions. The option premium is about $\mathbf{1 1 . 7 5 \%}$. 
Also we estimate the current value of the underlying asset at the time the premium is paid at about HK\$ 308,651,355, which is larger than the critical value of the underlying asset of this land option at the time the premium was paid(HK\$ 316,114,250). This means that this land option is an out-of-the-money call option and if this option is exercised immediately, the developer would suffer a reduced profit. The exercise practice of the developer at a later time conforms the predictions of the option theory.

\subsection{Results of Case 3-- Botania Villa}

\subsubsection{See the following graph for the estimation of variables}

\begin{tabular}{|c|c|}
\hline Variables & Estimation of Variables \\
\hline $\begin{array}{l}\text { Volatility of real estate asset returns } \\
\text { between } 1983 \text { to } 1996(\sigma)\end{array}$ & $\begin{array}{l}\text { From the repeat sales data, we estimate the } \\
\text { annual volatility of residential asset total returns } \\
\text { at about } \mathbf{2 6 . 8 3 \%} \text {. }\end{array}$ \\
\hline Dividend Yield of Land Option ( $\delta$ ) & $\begin{array}{l}\text { Dividend yield of land option is rental yield of } \\
\text { built property. We estimate the average rental } \\
\text { yield at about } 4.65 \% \text { at the time the premium } \\
\text { was paid. }\end{array}$ \\
\hline Risk-free Rate of Return & $\begin{array}{l}\text { The rate is } 5.56 \% \text { at the time the premium was } \\
\text { paid. }\end{array}$ \\
\hline $\begin{array}{c}\text { Strike Price (construction cost) of Land } \\
\text { Option }\end{array}$ & 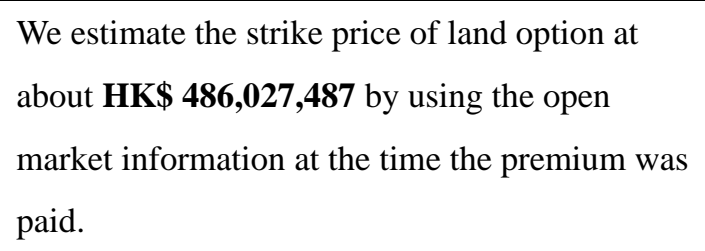 \\
\hline $\begin{array}{l}\text { Current Value of Underlying Asset (built } \\
\text { property) at the time land premium was } \\
\text { paid }\end{array}$ & $\begin{array}{l}\text { We estimate the current value of underlying asset } \\
\text { at about } \mathbf{H K \$ ~} \mathbf{8 6 6 , 0 8 9 , 8 5 2} \text { by using open market } \\
\text { information at the time the premium was paid. }\end{array}$ \\
\hline
\end{tabular}

\subsubsection{Option Pricing and Option (time) Premium}

By using option pricing methodology, we estimate the land premium at about HK\$ $258,544,866$. The land premium estimated by the government is HK\$ $184,870,000$. So the land premium estimated by the option pricing theory is larger than that of the government using residual method, which supports our propositions. The option premium is about $\mathbf{2 8 . 5 0 \%}$. Also we estimate the current value of the underlying asset at the time the premium is paid at about HK\$ 866,089,852, which is smaller than the critical value of the underlying asset of this land option at the time the premium was paid (HK\$1,209,073,954). This means that this land option is an out-of-the-money call option and if this option is exercised 
immediately, the developer would suffer a reduced profit. The exercise practice of the developer at a later time conforms the predictions of the option theory.

\section{Conclusion and Discussion}

From the real option analysis of the above three heterogeneous residential real estate projects in Hong Kong, we can see that hypothesis 1 and hypothesis 2 has been confirmed. The positive option premium shows that Hong Kong government has undervalued the land involved in the lease modification context. Since premiums present quite a significant portion of annual government revenue, especially during cyclical upturns in the real estate sector, the financial implications of the land premium also show that using the real option approach to value land can increase revenue to the government, which could help to alleviate the governments' fiscal constraints, presently fairly serious. Also, the results also confirmed the hypothesis that developers delayed the development of land to the point predicted by the real options model even when regulatory constraints are incorporated into the analyses.

Unlike Quigg(1993)'s methodology which applies same variables to one class of properties, we apply different variables to different projects. This would give us more reliable results on option premium in practice. This research could also facilitate the application of real option analysis to the practice of land valuation by applying a simple and easily applicable model to the valuation process. 


\section{Appendix: Summary Details of the Case 1}

The project is located in Fu Tei, Tuen Mun, New Territories of Hong Kong. The project name is Parkland Villas Block. The new grant LOT Number is 3121. Lease term is from 06/09/1994 to 30/06/2047. The total lot (land) area is about 21200 square meters. The new grant lot is consolidated from 8 small old lots which had been purchased by the developer from initial land owners. The developer should surrender the old lots to the government in exchange for the new grant lot. The premium calculated by the government for the land use

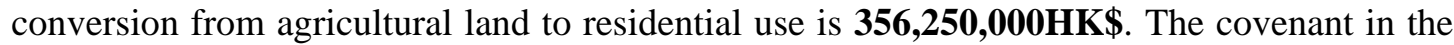
special conditions of the land use conversion contract states that "the Grantee shall pay to the Government on demand in one lump sum the amount of HK\$ 356,250,000 being the premium specified in the first schedule hereto". Here the Grantee is the developer of this land.

In the land use conversion contract signed between the government and the developer, I have specified some regulatory constrains embedded in it. The Regulatory constraints in the land conversion contract are as follows:

\begin{tabular}{|l|l|}
\hline $\begin{array}{l}\text { Building } \\
\text { Covenant }\end{array}$ & $\begin{array}{l}\text { The Grantee shall develop the lot by the erection thereon of a building or } \\
\text { buildings complying in all respects with these conditions and all Ordinances, } \\
\text { byelaws and regulations relating to building, sanitation and planning which are } \\
\text { or may at any time be in force in Hong Kong, such building or buildings to be } \\
\text { completed and made fit for occupation on or before the } 30 \text { day of September, } \\
\mathbf{1 9 9 8 .}\end{array}$ \\
\hline $\begin{array}{l}\text { Total } \\
\text { floor area }\end{array}$ & $\begin{array}{l}\text { The total gross floor area of any building or buildings erected or to be erected } \\
\text { thereon shall not be less than 35, 560 square meters and shall not exceed } \\
\mathbf{5 9 , 2 6 5} \text { square meters. }\end{array}$ \\
\hline User & $\begin{array}{l}\text { Subject to these Conditions, the lot or any part thereof or any building or part } \\
\text { of any building or to be erected thereon shall not be used for any purpose other } \\
\text { than private residential purpose. }\end{array}$ \\
\hline
\end{tabular}

\section{Time line for the Project:}

\begin{tabular}{|l|l|l|l|}
\hline $\begin{array}{l}\text { Time Point when the } \\
\text { developer purchased } \\
\text { the } 8 \text { small old lots }\end{array}$ & $\begin{array}{l}\text { Time Point when the } \\
\text { developer consolidated } \\
\text { the lots and paid the } \\
\text { land conversion } \\
\text { premium }\end{array}$ & $\begin{array}{l}\text { Time Point when the } \\
\text { developer started to } \\
\text { construct }\end{array}$ & $\begin{array}{l}\text { Time Point when the } \\
\text { developer began to } \\
\text { presell the residential } \\
\text { units to the public }\end{array}$ \\
\hline June, $\mathbf{1 9 8 7}$ & Sept. 1994 & Dec. $\mathbf{1 9 9 4}$ & Sept. 1997 \\
\hline
\end{tabular}




\section{Appendix: Summary Details of the Case 2}

The project is located in Castle Peak Road-Hung Shui Kiu, Tuen Mun, New Territories of Hong Kong. The project name is Bauhinia Garden. The New Grant LOT Number is 2998. Lease term is from 17/06/1992 to 30/06/2047. The total lot (land) area is about 12120 square meters. The new grant lot is consolidated from 19 small old lots which had been purchased by the developer from initial land owners. The developer should surrender the old lots to the government in exchange for the new grant lot. The premium calculated by the government for the land use conversion from agricultural land to residential use is $107,770,000 H K \$$. The covenant in the special conditions of the land use conversion contract states that "the Grantee shall pay to the Government on demand in one lump sum the amount of HK\$ 107,770,000 being the premium specified in the first schedule hereto". Here the Grantee is the developer of this land.

In the land use conversion contract signed between the government and the developer, I have specified some regulatory constrains embedded in it. The Regulatory constraints in the land conversion contract are as follows:

\begin{tabular}{|l|l|}
\hline $\begin{array}{l}\text { Building } \\
\text { Covenant }\end{array}$ & $\begin{array}{l}\text { The Grantee shall develop the lot by the erection thereon of a building or } \\
\text { buildings complying in all respects with these conditions and all Ordinances, } \\
\text { byelaws and regulations relating to building, sanitation and planning which are } \\
\text { or may at any time be in force in Hong Kong, such building or buildings to be } \\
\text { completed and made fit for occupation on or before the } \mathbf{3 0} \text { day of June, } \mathbf{1 9 9 5} .\end{array}$ \\
\hline $\begin{array}{l}\text { Total } \\
\text { gross }\end{array}$ & $\begin{array}{l}\text { The total gross floor area of any building or buildings erected or to be erected } \\
\text { thereon shall not be less than 9,148 square meters and shall not exceed } \mathbf{1 5 , 2 4 6} \\
\text { square meters. }\end{array}$ \\
\hline User & $\begin{array}{l}\text { Subject to these Conditions, the lot or any part thereof or any building or part } \\
\text { of any building or to be erected thereon shall not be used for any purpose other } \\
\text { than private residential purpose. }\end{array}$ \\
\hline
\end{tabular}

\section{Time line for the Project:}

\begin{tabular}{|l|l|l|l|}
\hline $\begin{array}{l}\text { Time Point when the } \\
\text { developer purchased } \\
\text { the } 19 \text { small old lots }\end{array}$ & $\begin{array}{l}\text { Time Point when the } \\
\text { developer consolidated } \\
\text { the lots and paid the } \\
\text { land conversion } \\
\text { premium }\end{array}$ & $\begin{array}{l}\text { Time Point when the } \\
\text { developer started to } \\
\text { construct }\end{array}$ & $\begin{array}{l}\text { Time Point when the } \\
\text { developer began to } \\
\text { presell the residential } \\
\text { units to the market }\end{array}$ \\
\hline $\mathbf{1 9 3 3}$ & Jun. 1992 & Sept. 1992 & Jun. 1994 \\
\hline
\end{tabular}




\section{Appendix: Summary Details of the Case 3}

The project is located in Lam Tei, Tuen Mun, New Territories of Hong Kong. The project name is Botania Villa. The New Grant LOT Number is 3205. Lease term is from 01/05/1996 to 30/06/2047. The total lot (land) area is about 22348 square meters. The new grant lot is consolidated from 14 small old lots which had been purchased by the developer from initial land owners. The developer should surrender the old lots to the government in exchange for the new grant lot. The premium calculated by the government for the land use conversion from agricultural land to residential use is $184,870,000 \mathrm{HK}$. The covenant in the special conditions of the land use conversion contract states that "the Grantee shall pay to the Government on demand in one lump sum the amount of HK\$ 184,870,000 being the premium specified in the first schedule hereto". Here the Grantee is the developer of this land.

In the land use conversion contract signed between the government and the developer, I have specified some regulatory constrains embedded in it. The Regulatory constraints in the land conversion contract are as follows:

\begin{tabular}{|l|l|}
\hline $\begin{array}{l}\text { Building } \\
\text { Covenant }\end{array}$ & $\begin{array}{l}\text { The Grantee shall develop the lot by the erection thereon of a building or } \\
\text { buildings complying in all respects with these conditions and all Ordinances, } \\
\text { byelaws and regulations relating to building, sanitation and planning which are } \\
\text { or may at any time be in force in Hong Kong, such building or buildings to be } \\
\text { completed and made fit for occupation on or before the } \mathbf{3 0} \text { day of June, } \mathbf{2 0 0 0} .\end{array}$ \\
\hline $\begin{array}{l}\text { Total } \\
\text { gross }\end{array}$ & $\begin{array}{l}\text { The total gross floor area of any building or buildings erected or to be erected } \\
\text { thereon shall not be more than } \mathbf{4 3 , 6 5 0} \text { square meters and shall not be less than } \\
\text { 26, } 190 \text { square meters. }\end{array}$ \\
\hline User & $\begin{array}{l}\text { 11(a)Subject to these Conditions and in particular subject to sub-clause (b) of } \\
\text { this special condition, the lot or any part thereof or any building or part of any } \\
\text { building or to be erected thereon shall not be used for any purpose other than } \\
\text { private residential purpose. (b) the grantee shall erect, construct and provide } \\
\text { with the lot a public toilet, a public open space and a public vehicle park. }\end{array}$ \\
\hline
\end{tabular}

Time line for the Project:

\begin{tabular}{|l|l|l|l|}
\hline $\begin{array}{l}\text { Time Point when the } \\
\text { developer purchased } \\
\text { the } 19 \text { small old lots }\end{array}$ & $\begin{array}{l}\text { Time Point when the } \\
\text { developer consolidated } \\
\text { the lots and paid the } \\
\text { land conversion } \\
\text { premium }\end{array}$ & $\begin{array}{l}\text { Time Point when the } \\
\text { developer started to } \\
\text { construct }\end{array}$ & $\begin{array}{l}\text { Time Point when the } \\
\text { developer began to } \\
\text { presell the residential } \\
\text { units to the market }\end{array}$ \\
\hline $\mathbf{1 9 9 1 , \mathbf { 1 9 9 2 , 1 9 9 5 }}$ & May. 1996 & Sept. 1996 & Jun. 1999 \\
\hline
\end{tabular}




\section{References:}

Brennan M. and Schwartz E. (1985), “Evaluating Natural Resource Investments”, Journal of Business (April), pp.135-157.

Bulan, Mayer and Somerville (2002), "Irreversible Investment, Real Options, and Competition: Evidence from Real Estate Development”, Working paper, UBC Commerce Center for Urban Economics and Real Estate.

Capozza, D.and Helsley, R. W. (1990), “The Stochastic City”, Journal of Urban Economics 28, 187-203.

Capozza, D. and Li Y. (1994), "The Intensity and Timing of Investment: The Case of Land”, The American Economic Review (4), Vol. 84, pp.889-904.

Capozza, D. and Schwann, G.(1990), “The Value of Risk in Real Estate Markets”, Journal of Real Estate Finance and Economics 3, pp.117-140.

Capozza , D. and Sick, G. (1994), “The Risk Structure of Land Markets”, Journal of Urban Economics 35, 297-319.

Holland, Ott and Riddiough(2000), "the Role of Uncertainty in Investment: an Examination of Competing Investment Models Using Commercial Real Estate Dada”, Real Estate Economics 28, 1: pp.33-64.

McDonald R. and Siegel D. (1986), “The Value of Waiting to Invest,” Quarterly Journal of Economics (November), pp. 707-727.

Moel and Tufano(2002), "When are Real Options Exercised? An Empirical Study of Mine Closings”, the Review of Financial Studies, Vol.15, No.1, pp.35-64.

Quigg L. (1993), “Empirical testing of real option-pricing Models”, The Journal of Finance 48, 621-640.

Samuelson, P.A. (1965), "Rational theory of Warrant Pricing”, Industrial Management Review (pre-1986), pp.13-39.

Shilling, J., Sirmans, C., Turnbull, G. and Benjamin J. (1990), “A Theory and Empirical Test of Land Option Pricing,” Journal of Urban Economics 28, pp.178-186. 
Sing and Patel (2001a), "Empirical evaluation of the value of waiting to invest”, Journal of property investment and Finance, Vol.19, No.6, pp.535-553.

Sing and Patel (2001b), "Evidence of irreversibility in the UK property market", the quarterly review of economics and finance 41, pp.313-334.

Sivitanidou, R. and Sivitanides, P. (2000), "Does the Theory of Irreversible Investments Help Explain Movements in Office-Commercial Construction?” Real Estate Economics 28, pp.623-661.

Somerville (2001), "Permits, Starts, and Completions: Structural Relationships versus Real Options”, Real Estate Economics 29, 1: pp. 161-190.

Wong Siu Kei (2003), “The Performance of Property Companies in Hong Kong: a Style Analysis Approach”, Ph.D. thesis, the University of Hong Kong.

Yamazaki R. (2001), “Empirical testing of real option pricing models using Land Price Index in Japan”, Journal of Property Investment \& Finance, Vol.19 No. 1, pp.53- 72.

Ying Kong Chau, Willam(1993), “Lease Modification and Urban Planning”, workshop report, center of urban planning and environmental management, university of Hong Kong. 